\title{
Chronically Sun-exposed Site
}

National Cancer Institute

\section{Source}

National Cancer Institute. Chronically Sun-exposed Site. NCI Thesaurus. Code C129466.

An area of the body subjected to consistent and repetitive sun exposure. 